\title{
Perancangan Aplikasi Penilaian Tingkat Kesehatan Bank Umum Menggunakan Metode Risk Based Bank Rating
}

\author{
Design of a commercial banks 'bealth rating assessment application using risk based bank \\ rating method
}

\section{Maulana Harun Ar-rosyyid}

Program Studi D3 Keuangan dan Perbankan, Politeknik Negeri Bandung

E-mail: maulana.harun.kepn17@polban.ac.id

\section{Destian Arshad Darulmalshah Tamara}

Jurusan Akuntansi, Politeknik Negeri Bandung

E-mail: destian.arshad@polban.ac.id

\section{Rosma Pakpahan}

Jurusan Akuntansi, Politeknik Negeri Bandung

E-mail: rosma.pakpahan@polban.ac.id

\begin{abstract}
The soundness level of a bank is a qualitative assessment of various aspects that affect the condition or performance of a bank through quantitative or quantitative assessments. In this Regulation of the Financial Services Authority Number 4 / POJK.03 / 2016 using an individual and consolidated risk approach (Risk Based Bank Rating / RBBR). This risk approach includes the Risk Profile, Good Corporate Governance, Earnings and Capital factors. Conducting an assessment is not easy, especially if it is still manual for the process. That way designing an application is the right way to solve it because it can simplify the work process by utilizing existing technology capabilities. Android-based technology is one of the most dominating technologies in use throughout the world. This study aims to design an application to process financial report data for the commercial bank sector into information on the bealth level of commercial banks based on the RBBR method and to present the development (comparison) of the soundness level of commercial banks in a two years period with the help of an android-based application. The design of this application uses a prototype approach method with several stages, namely identifying needs, making prototypes, testing prototypes, improving prototypes and developing production versions. Then the trial was carried out at one commercial bank for two consecutive periods at once. The test results on the application design for calculating the soundness level of a commercial bank based on the RBBR method in accordance with applicable regulations have been able to determine the composite rating (PK) and can suggest developments (comparisons) on the NPL, GCG, ROA and CAR factors in one commercial bank for two consecutive periods at once.
\end{abstract}

Keywords: android application, risk based bank rating, bank soundness level

\section{Pendahuluan}

Melakukan penilaian bukanlah hal yang mudah, terlebih jika masih bersifat manual untuk proses pengerjaannya. Dengan begitu merancang aplikasi merupakan cara yang tepat untuk mengatasinya karena dapat mempermudah proses pekerjaan dengan memanfaatkan kemampuan teknologi yang ada. Teknologi berbasis android merupakan salah satu teknologi yang paling 
mendominasi dalam pemakaian diseluruh dunia.

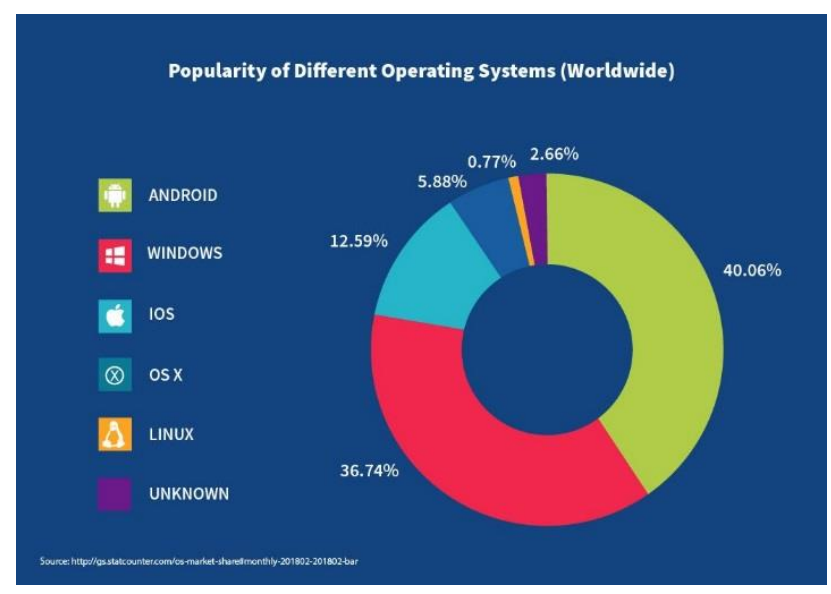

Gambar 1. Persentase Penggunaan Sistem Operasi di Dunia tahun 2020 (Wizcase, 2020)

Dalam halaman web (detikfinance, 2020) menyebutkan "perbankan Republik Indonesia turun 2\% menjadi 20\% yang sebelumnya 22\%." Pada tanggal 10 juni 2020 menurut halaman web (Kontan, 2020) menyebutkan "terdapat beberapa bank yang selalu bermasalah. Dalam melakukan fungsi pengawasan OJK terhadap tujuh bank belum sesuai ketentuan antara lain menyangkut rasio kecukupan modal atau CAR, batas minimum pemberian kredit (BMPK), kelalaian direktur dan juga kesalahan penyaluran kredit."

Risk Profile dalam penelitian ini menggunakan Risiko Kredit. Dalam perbankan risiko kredit menjadi hal yang tidak dapat biarkan begitu saja karena kredit pada perbankan menjadi titik utama atau yang paling dominan dalam menghasilkan laba perusahaan (Danisworo, 2017). Dalam risiko kredit, peneliti menggunakan rasio Non Performing Loan (NPL). Semakin besar NPL, maka menunjukan kualitas pemberian kredit bank umum semakin buruk. Earning sangat penting bagi perusahaan karena dapat mencerminkan keberhasilan dan kelangsungan hidup suatu perusahaan. Rasio Earning merupakan rasio yang menilai kemampuan perusahaan dalam menghasilkan laba selama periode tertentu (Lestari dkk, 2020). Dalam Rasio Earning, peneliti menggunakan rasio Return on Asset (ROA). Tujuan menggunakan ROA adalah mengukur aset bank dalam menghasilkan laba. Semakin besar ROA, maka semakin efisien penggunaan aktiva perusahaan atau dengan kata lain semakin besar ROA, maka semakin besar laba yang dihasilkan (Hijriyani dan Setiawan, 2017). Dalam perbankan Rasio ROA dihitung pada Laba sebelum pajak terhadap total aset. Aset pada perusahaan perbankan lebih dominan berasal dari penyaluran dana pihak ketiga yang merupakan bukan dari bagian capital inti perusahaan. Dalam mengukur tingkat kesehatan pada faktor capital, peneliti menggunakan rasio Capital Adequacy Ratio (CAR). Tujuan penggunaan CAR adalah mengukur modal bank dalam mengatasi kerugian dan Kewajiban Penyediaan Modal Minimum (KPMM), semakin solvable apabila rasio ini meningkat (Taruna dan Setiawan, 2019).

Penelitian ini bertujuan untuk merancang aplikasi untuk mengolah data laporan keuangan sektor bank umum menjadi informasi tingkat kesehatan bank umum berdasarkan metode RBBR dan dapat mengemukakan tentang perkembangan (komparasi) tingkat kesehatan bank umum dalam periode waktu dua tahun dengan bantuan aplikasi berbasis android.

\section{Kajian Pustaka}

\subsection{Tingkat Kesehatan Bank}

Dari POJK "Tingkat Kesehatan Bank adalah hasil penilaian kondisi Bank yang dilihat dari kinerja dan risiko Bank.” (Otoritas Jasa Keuangan, 2016) Dan "tingkat kesehatan bank diartikan sebagai kemampuan bank untuk melakukan kegiatan operasional perbankan dengan normal dan 
mampu melaksanakan semua kewajibannya dengan baik dengan cara-cara yang sesuai dengan peraturan perbankan yang berlaku." (Kasmir, 2008)

\subsection{Alat Ukur Penilaian Tingkat Kesehatan Bank}

Dalam POJK "alat ukur dalam penilaian tingkat kesehatan bank umum menggunakan pendekatan risiko (Risk Based Bank Rating / RBBR) secara individu dan konsolidasi (antara Bank dengan Perusahaan Anak)." (Otoritas Jasa Keuangan, 2016) Pendekatan RBBR memiliki empat faktor yaitu:

\section{2.a. Risk Profile}

Dari POJK "Risk Profile (Profil risiko) merupakan penilaian terhadap risiko inheren dan kualitas penerapan manajemen risiko dalam operasional Bank, ada 8 risiko dalam risk profile yaitu risiko operasional, risiko hukum, risiko likuiditas, risiko kredit, risiko pasar, risiko reputasi, risiko kepatuhan dan risiko stratejik." (Otoritas Jasa Keuangan, 2016) Penilaian Risk Profile pada risiko kredit diukur dengan memakai rasio Non Performing Loan (NPL) menggunakan rumusaberikut :

$$
N P L=\frac{(\text { Kredit Bermasalah })}{(\text { Total Kredit })} \times 100 \%
$$

Tabel 1. Kriteria Peringkat risiko kredit (Bank Indonesia, 2014)

\begin{tabular}{|c|c|c|}
\hline Peringkat & Keterangan & Kriteria \\
\hline 1 & Sangat Sehat & NPL $\leq 7 \%$ \\
\hline 2 & Sehat & $7 \%<$ NPL $\leq 10 \%$ \\
\hline 3 & Cukup Sehat & $10 \%<$ NPL $\leq 13 \%$ \\
\hline 4 & Kurang Sehat & $13 \%<$ NPL $\leq 16 \%$ \\
\hline 5 & Tidak Sehat & NPL $>16 \%$ \\
\hline
\end{tabular}

\section{2.b. Good Corporate Governance (GCG)}

Dari POJK "Good Corporate Governance (GCG) merupakan penilaian terhadap manajemen Bank atas pelaksanaan prinsip-prinsip GCG." (Otoritas Jasa Keuangan, 2016) Merujuk pada SEOJK "GCG yang baik merupakan struktur dan proses yang digunakan atau diterapkan oleh perusahaan untuk meningkatkan pencapaian sasaran hasil usaha dan mengoptimalkan nilai Perusahaan secara akuntabel yang berlandaskan peraturan perundang-undangan serta nilai-nilai etika." (Otoritas Jasa Keuangan, 2017)

Tabel 2. Kriteria Peringkat GCG (Bank Indonesia, 2014)

\begin{tabular}{|c|c|}
\hline Peringkat & Keterangan \\
\hline 1 & Sangat Baik \\
\hline 2 & Baik \\
\hline 3 & Cukup Baik \\
\hline 4 & Kurang Baik \\
\hline 5 & Tidak Baik \\
\hline
\end{tabular}

\section{2.c. Earnings}

Dari POJK "Earnings meliputi penilaian terhadap kinerja rentabilitas (earnings), sumbersumber rentabilitas (earnings), dan kesinambungan rentabilitas (earnings' sustainability) Bank." (Otoritas Jasa Keuangan, 2016) Penilaian earnings diukur dengan menggunakan rasio Return On Asset (ROA) dengan menggunakan rumus sebagai berikut : 
$R O A=\frac{(\text { Laba Sebelum Pajak })}{(\text { Rata }- \text { rata Total Aset })} \times 100 \%$

Tabel 1. Kriteria Peringkat Earnings (ROA)

\begin{tabular}{|c|c|c|}
\hline Peringkat & Keterangan & Kriteria \\
\hline 1 & Sangat Sehat & ROA $>1,45 \%$ \\
\hline 2 & Sehat & $1.215 \%<\mathrm{ROA} \leq 1,45 \%$ \\
\hline 3 & Cukup Sehat & $0,999 \%<\mathrm{ROA} \leq 1,215 \%$ \\
\hline 4 & Kurang Sehat & $0,765 \%<\mathrm{ROA} \leq 0,999 \%$ \\
\hline 5 & Tidak Sehat & ROA $\leq 0,765 \%$ \\
\hline
\end{tabular}

\section{2.d. Capital}

Dari POJK "Capital meliputi penilaian terhadap tingkat kecukupan permodalan dan pengelolaan permodalan." (Otoritas Jasa Keuangan, 2016) Penilaian capital diukur dengan menggunakan rasio Capital Adequacy Ratio (CAR) dengan menggunakan rumus sebagai berikut :

$C A R=\frac{(\text { Modal Bank })}{(\text { Aktiva Tertimbang Menurut Risiko })} \times 100 \%$

Tabel 1. Kriteria Peringkat Capital (CAR)

\begin{tabular}{|c|c|c|}
\hline Peringkat & Keterangan & Kriteria \\
\hline 1 & Sangat Sehat & CAR $\geq 11 \%$ \\
\hline 2 & Sehat & $9,5 \% \leq \mathrm{CAR}<11 \%$ \\
\hline 3 & Cukup Sehat & $8 \% \leq \mathrm{CAR}<9,5 \%$ \\
\hline 4 & Kurang Sehat & $6,5 \%<\mathrm{CAR}<8 \%$ \\
\hline 5 & Tidak Sehat & CAR $\leq 6,5 \%$ \\
\hline
\end{tabular}

Tabel 1. Peringkat Komposit

\begin{tabular}{|c|c|}
\hline Peringkat Komposit & Keterangan \\
\hline PK-1 & Sangat Sehat \\
\hline PK-2 & Sehat \\
\hline PK-3 & Cukup Sehat \\
\hline PK-4 & Kurang Sehat \\
\hline PK-5 & Tidak Sehat \\
\hline
\end{tabular}

\subsection{Aplikasi}

"Aplikasi adalah alat bantu untuk mempermudah dan mempercepat proses pekerjaan dan bukan merupakan beban bagi para pengguna.” (Ibisa, 2009)

\subsection{Android}

"Android merupakan generasi baru platform mobile, platform yang memberikan pengembang untuk melakukan pengembangan sesuai dengan yang diharapkannya." (Safaat, 2015)

\subsection{Android Studio}

Android Studio adalah IDE untuk sistem operasi Android yang didesain khusus untuk pengembangan aplikasi Android. Android Studio merupakan aplikasi pengganti dari Eclipse IDE.

\subsection{Prototype}

"Prototype merupakan suatu metode untuk membuat suatu program dengan cepat dan 
bertahap dengan menggunakan pendekatan sehingga dapat dievaluasi oleh pemakai." (Abdul, 2014)

\subsection{Use Case}

"Use case diagram hanya memberi gambaran singkat tentang hubungan antara use case, aktor, dan sistem dan tidak menjelaskan secara detail menyeluruh tiap penggunaan use case." (Shalahuddin \& Rosa, 2015)

\subsection{Data Flow Diagram}

"Data Flow Diagram adalah gambaran grafis yang memperlihatkan aliran data dalam objek kemudian melewati suatu proses yang kemudian ditransformasikan pada objek lain.” (Wijaya, 2007)

\section{Metodologi Pelaksanaan}

Metode penelitian yang digunakan oleh penulis adalah metode penelitian komparatif. Penelitian komparatif yang dilakukan dengan membandingkan teori yang ada dengan peraktik yang ditemui dan menarik kesimpulan.

\subsection{Metode Pendekatan Sistem}

Dalam memudahkan pengerjaan penelitian yang berhubungan dengan masalah yang diteliti, maka penulis menggunakan pendekatan bagan alir data yang di visualisasikan dengan DFD (Data Flow Diagram) yang dibantu dengan pendekatan oerientasi objek dengan Use Case Diagram.

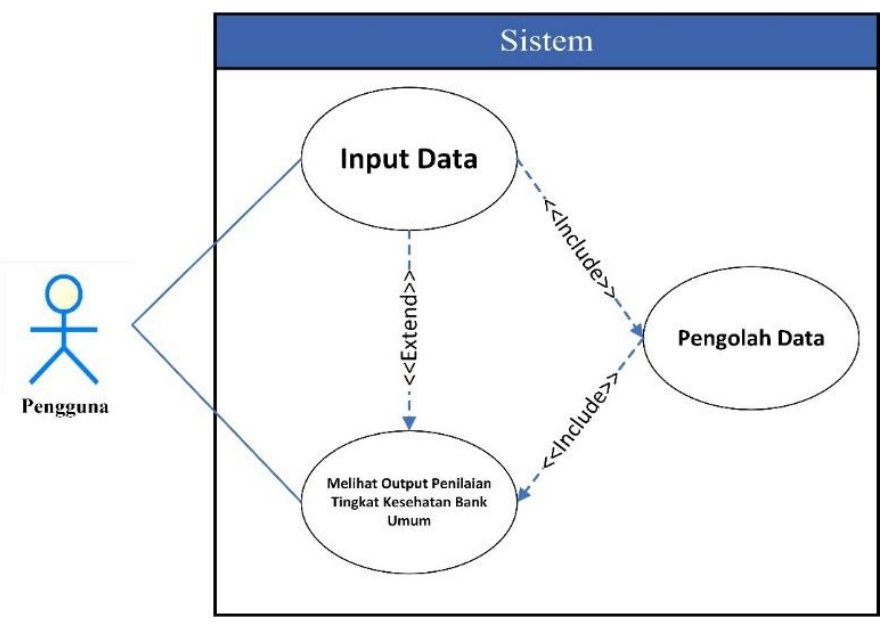

Gambar 2. Use Case Diagram

\subsection{Metode Pengembangan Sistem}

Dalam pengembangan sistem di perancangan aplikasi ini menggunakan metode pendekatan prototype yang dibangun untuk mendefinisikan. Tahapan yang dilakukan dalam metode prototype ini antara lain :

1. Tahap awal dilakukan analisis kebutuhan, proses ini dilakukan untuk mengetahui informasi, model, dan spesifikasi dari sistem yang dibutuhkan.

2. Dalam tahap ini akan dilakukan pembuatan dan perancangan sementara prototype sesuai dengan kebutuhan.

3. Pada tahap ini dimulainya proses pengujian yang dilakukan oleh pemakai untuk selanjutnya memberikan kritik dan saran kepada pengembang.

4. Pengembang melakukan modifikasi atau perbaikan sesuai dengan masukan dari pemakai.

5. Pengembang merampungkan sistem sesuai dengam masukan terakhir dari pemakai. 


\subsection{Perancangan Aplikasi}

\section{3.a. Bagan Alir (Flow Chart)}



Gambar 3. Flow Chart

\section{3.b. Bagan Alir Data (Data Flow Chart)}

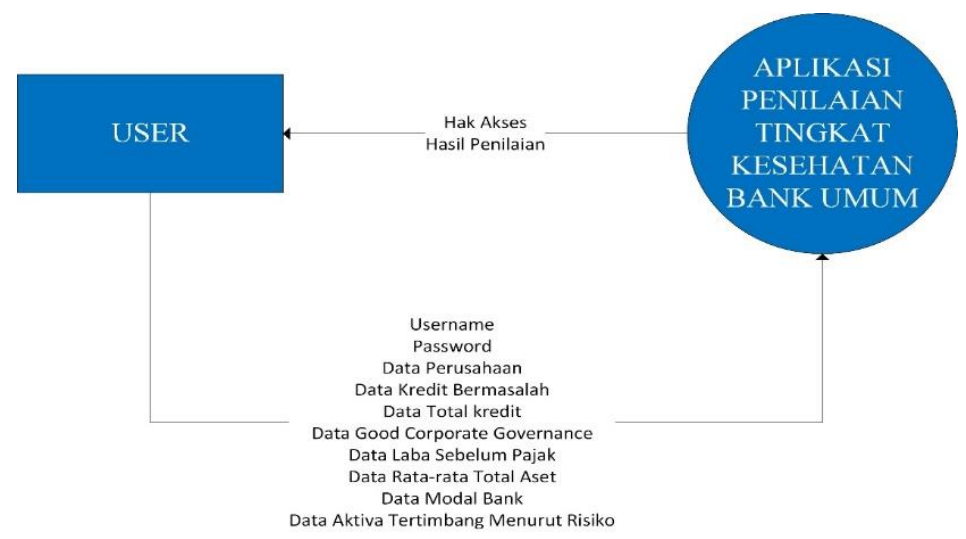

Gambar 4. DFD Level 0 


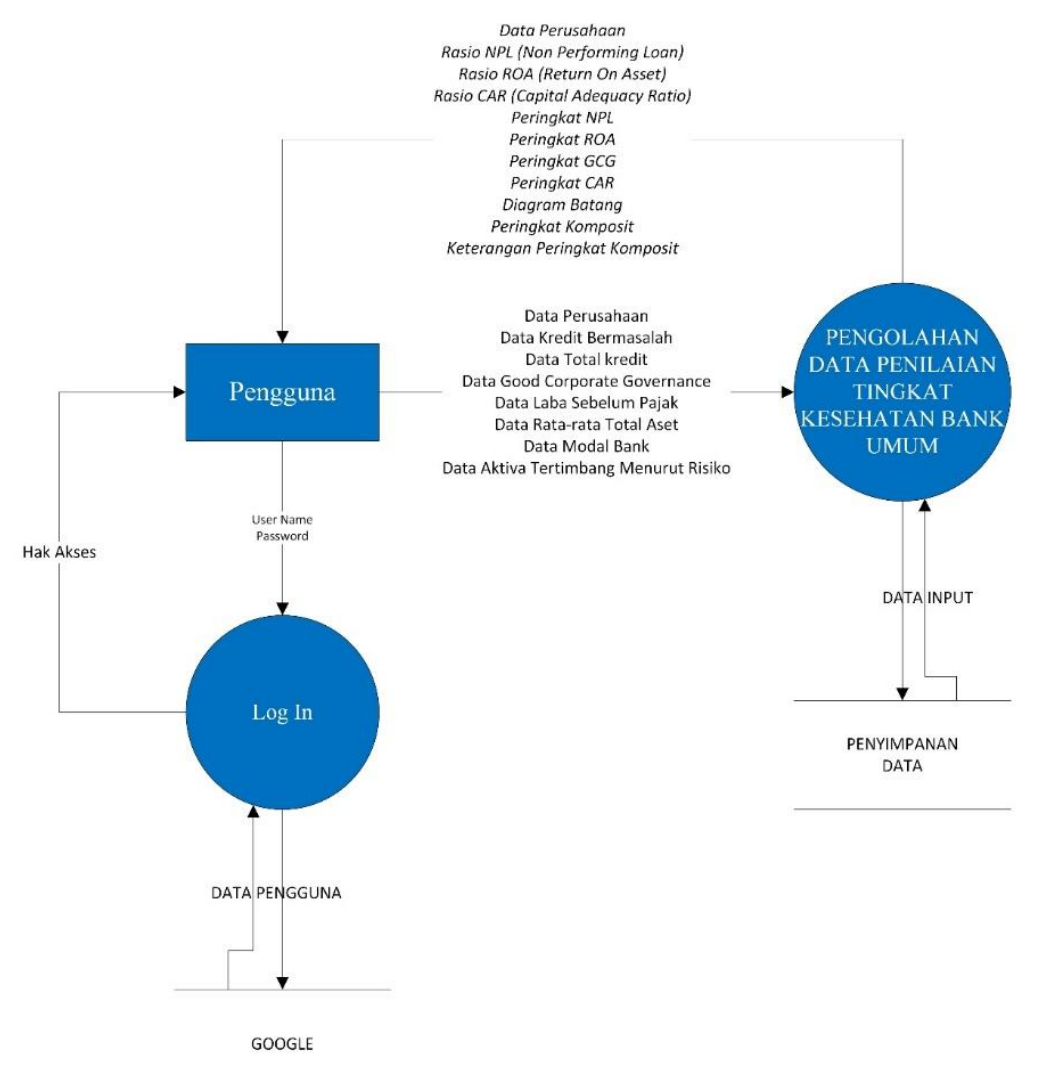

Gambar 5. DFD Level 1

\section{Hasil dan Pembahasan}

\subsection{Perancangan Sistem Tampilan Awal \& Login}

Dalam tahap ini penulis akan merancang tampilan awal dengan menampilkan gambar welcome dalam durasi 3 detik yang selanjutnya akan otomatis menampilkan tampilan Login atau Menu Dashboard. Apabila pengguna baru pertama kali atau belum melakukan login, maka setelah tampilan awal akan berganti pada tampilan Login yang mengharuskan pengguna melakukan login akun google untuk aplikasi ini. Dan apabila sudah pernah melakukan login pada aplikasi ini, maka tampilan awal akan secara otomatis berganti pada tampilan Menu Dashboard.

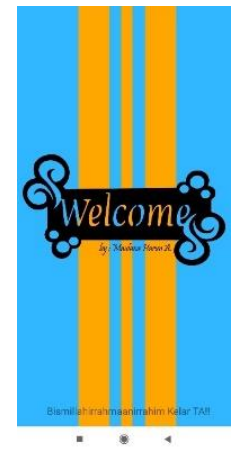

Gambar 6. Tampilan Awal 




Gambar 7. Tampilan Login

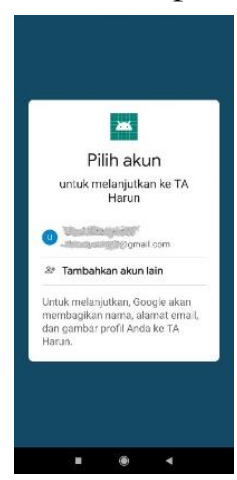

Gambar 8. Tampilan Pilih Akun Google

\subsection{Perancangan Sistem Menu Dashboard}

Dalam tahap ini penulis akan merancang sistem Menu Dashboard. Terdapat tampilan Beranda, tampilan Arsip Download File, tampilan Menu Navigasi dan tampilan Profile.



Gambar 9. Tampilan Beranda (Menu Dashboard)

Berikut adalah penjelasan dari sistem Menu Dashboard diatas:

a. Menu : akan menampilkan navigasi menu yang akan tampil dari sebelah kanan tampilan.

b. Profil : akan menampilkan tampilan profil akun google.

c. Tombol Baru : akan menampilkan tampilan input data.

d. Tombol Arsip : akan menampilkan tampilan arsip yang di dalamnya terdapat link untuk men-download file seperti file Peraturan dan SEOJK dan PBI.

e. Terdapat teks nama aplikasi, logo Polban dan teks pembuat aplikasi. 


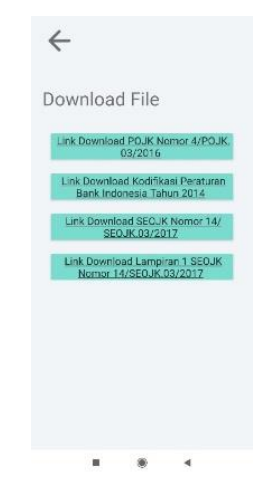

Gambar 10. Tampilan Arsip Download File



Gambar 11. Tampilan Menu Navigasi



Gambar 12. Tampilan Profile

\subsection{Perancangan Sistem Penginputan Data}

Dalam tahap ini penulis akan merancang sistem penginputan data, berupa penginputan data perusahaan perbankan, data kredit bermasalah, data total kredit yang diberikan, data Good Corporate Governance, data laba sebelum pajak, data rata-rata total asset, data modal bank dan data aktiva tertimbang menurut risiko. Dalam peng-input-an data, penulis menggunakan contoh data laporan keuangan milik Bank Tabungan Negara (BBTN) tahun 2019 dan tahun 2018. 


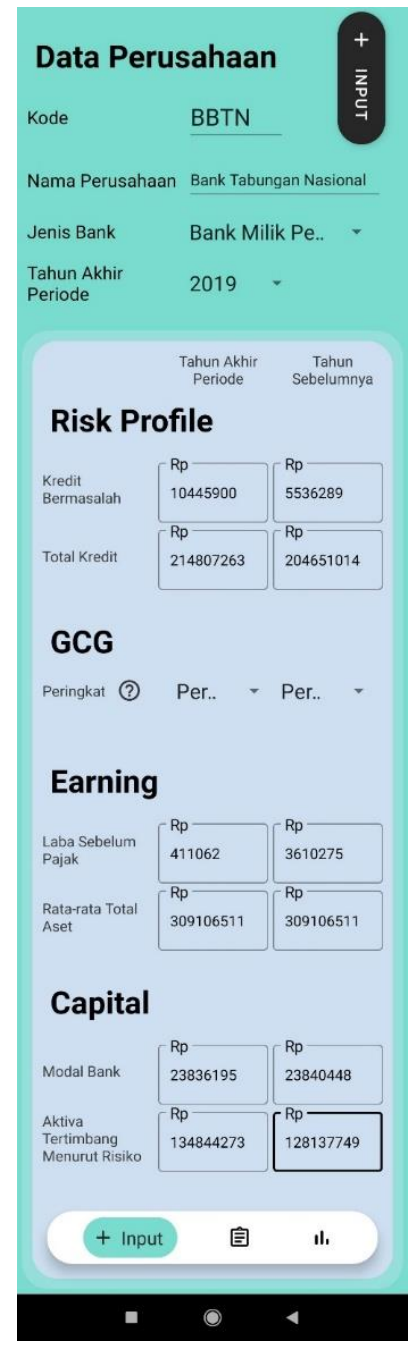

Gambar 13. Tampilan Input Data

Berikut adalah penjelasan dari sistem penginputan data diatas

a. Kode : input kode perusahaan perbankan .

b. Nama Perusahaan : input nama perusahaan perbankan yang akan diolah datanya.

c. Jenis Bank : Pilihan Jenis Bank berdasarkan kepemilikannya, seperti Bank BUMN, Bank BUMS, Bank Campuran, Bank Asing dan Bank Koperasi (BUMK).

d. Tahun Akhir Periode : tahun akhir periode pada laporan keuangan.

e. Tahun Sebelumnya : satu tahun sebelum tahun akhir periode.

f. Risk Profile : merupakan salah satu penilaian dari metode RBBR berdasarkan POJK No.4/POJK.03/2016.

g. Input Kredit Bermasalah : input jumlah kredit kepada pihak ketiga bukan bank yang tergolong kurang lancar, diragukan dan macet dari tahun akhir periode dan tahun sebelumnya.

h. Input Total Kredit : input total kredit yang diberikan kepada pihak ketiga bukan bank dari tahun akhir periode dan tahun sebelumnya.

i. GCG : merupakan salah satu penilaian dari metode RBBR berdasarkan POJK No 4/POJK.03/2016.

j. Earning : merupakan salah satu penilaian dari metode RBBR berdasarkan POJK No 4/POJK.03/2016.

k. Input Laba Sebelum Pajak : input laba sebelum pajak pada laporan keuangan (SEOJK 
No 14/SEOJK.03/2017).

1. Input Rata-rata Total aset : input rata-rata total aset, untuk mencari rata-rata total aset pada tahun akhir periode adalah penjumlahan tahun akhir periode dengan tahun sebelumnya kemudian dibagi dua(2), begitu pula untuk tahun sebelumnya.

m. Capital : merupakan salah satu penilaian dari metode RBBR berdasarkan POJK No 4/POJK.03/2016.

n. Input Modal Bank : input modal bank yang berada pada laporan posisi keuangan bank tahun akhir periode dan tahun sebelumnya.

o. Input Aktiva Tertimbang Menurut Risiko : input ATMR yang berada pada Catatan Atas Laporan Keuangan tahun akhir periode dan tahun sebelumnya.

p. Tombol Input : menyimpan dan mengolah semua data yang di input pada penyimpanan data.

q. Menu Input : menampilkan form input data.

r. Menu Rasio : menampilkan form rasio.

s. Menu Nilai : menampilkan form hasil output pengolah data keseluruhan.

\subsection{Perancangan Sistem Pengolahan Data}

Dalam tahap ini akan menampilkan hasil pengolahan data yang telah input dalam tampilan pengolahan rasio dan pengolahan peringkat keseluruhan berupa tabel berisi data yang di input dan hasil pengolahan rasio, diagram batang dan keterangan dari Peringkat Komposit (PK).

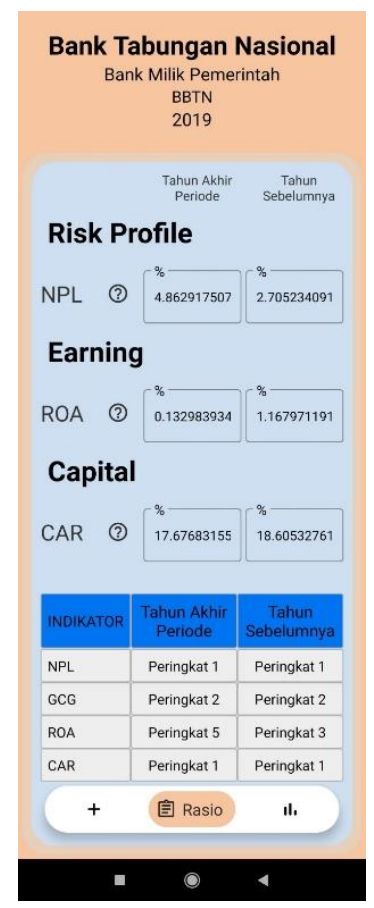

Gambar 14. Tampilan Hasil Pengolahan Rasio

Dengan menekan menu Rasio, akan otomatis menampilkan hasil pengolahan rasio dari datadata yang sudah di input. Dalam tampilan ini pengguna dapat melihat rasio-rasio yang dibutuhkan dalam penilaian tingkat Kesehatan bank umum menggunakan metode RBBR. 


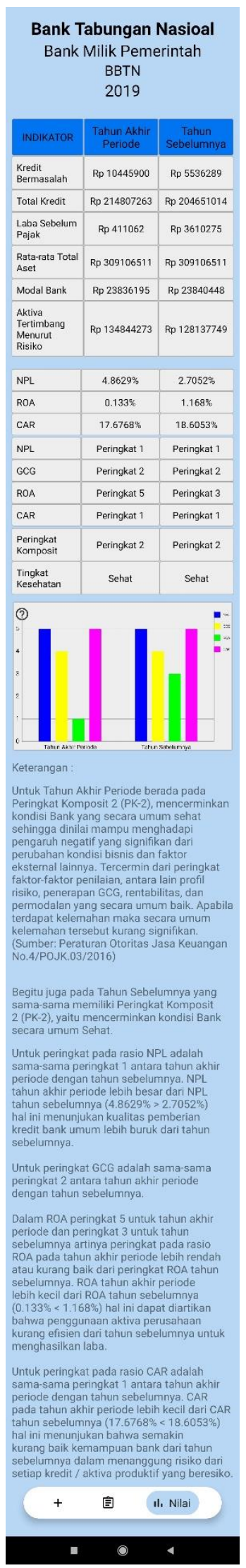

Gambar 15. Tampilan Hasil Peringkat Keseluruhan 
Dengan menekan menu Nilai, akan otomatis menampilkan pengolahan peringkat keseluruhan dari data-data yang sudah di input pada tampilan input data. Pada tampilan ini, pengguna dapat melihat hasil peringkat keseluruhan penilaian tingkat Kesehatan bank Umum berupa data yang sudah diinput dalam periode waktu dua tahun, data rasio dan peringkat rasio yang telah diolah oleh sistem dalam periode waktu dua tahun, peringkat komposit dalam periode waktu dua tahun, diagram batang dalam periode waktu dua tahun dan keterangan komparasi dari hasil peringkat komposit dalam periode waktu dua tahun.

Dengan demikian dari hasil uji coba ini, maka aplikasi sudah dapat melakukan penilaian tingkat kesehatan bank Umum dan melihat perkembangan (komparasi) bank Umum dengan metode RBBR sesuai ketentuan POJK No 4/POJK.03/2016.

\section{Penutup}

\subsection{Kesimpulan}

1. Hasil uji coba atas rancangan aplikasi penghitungan tingkat kesehatan bank umum berdasarkan metoda RBBR sesuai dengan PBI, telah dapat menentukan peringkat komposit (PK) satu bank umum selama dua periode berturut-turut sekaligus.

2. Hasil uji coba aplikasi pada bab sebelumnya juga sudah dapat mengemukakan perkembangan (komparasi) pada faktor NPL, GCG, ROA dan CAR pada satu bank umum selama periode waktu dua tahun.

\subsection{Saran}

1. Adanya pengembangan aplikasi lanjutan kedalam bentuk basis web internet yang dapat digunakan oleh semua sistem operasi dan perangkat.

2. Adanya pengembangan aplikasi lanjutan untuk melengkapi faktor Risk Profile, melengkapi faktor Earnings seperti Net Interest Margin dan sumber-sumber yang mendukung Rentabilitas / Earning, dan melengkapi faktor Capital lainnya.

3. Adanya penambahan periode penilaian untuk melihat tren perkembangan kesehatan perusahaan.

\section{Daftar Pustaka}

Abdul, K. (2014). Pengenalan Sistem Informasi Edisi Revisi. Yogyakarta: Andi Offest.

Bank Indonesia. (2014, Januari 3). Kodifikasi Peraturan Bank Indonesia Kelembagaan Penilaian Tingkat Kesehatan Bank. Retrieved from https://www.bi.go.id/id/peraturan/kodifikasi/bank/Pages/1.3.3.2.\%20Penilaian\%20Tin gkat $\% 20$ Kesehatan $\% 20$ Bank.aspx

Danisworo, D. S. (2017). Using The Exposure Based Cash Flow At Risk Approach To Estimate The Liquidity Risk: An Application For The Indonesian Banks. Proceedings of International Conference and Doctoral Colloquium in Finance

Detik. (2020, Juni 22). Diambil kembali dari detikfinance: https://finance.detik.com/moneter/d5063267/ada-bank-ri-yang-kolesterol-tinggi-bos-ojk-secara-nasional-sehat

Hijriyani, N. Z., \& Setiawan, S. (2017). Analisis Profitabilitas Perbankan Syariah di Indonesia sebagai Dampak Dari Efisiensi Operasional. Jurnal Kajian Akuntansi, 1(2), 194-209

Ibisa. (2009). Evaluasi Paket Sistem Aplikasi "Sistem Evaluasi dan Auditing sistem. Yogyakarta: ANDI Offset.

Kasmir. (2008). Bank dan Lembaga Keuangan Lainnya. Jakarta: PT. Raja Grafindo Persada.

Kontan. (2020, Juni 10). Diambil kembali dari Kontan: https://keuangan.kontan.co.id/news/inilah-kondisi-terkini-7-bank-yang-dalam-audit-ojk- 
oleh-bpk-lemah-pengawasannya?page=all

Lestari, H. T., Setiawan, S., \& Tripuspitorini, F. A. (2020). Risk Profile, Good Corporate Governance, Earning, dan Capital dalam Memprediksi Financial Distress pada Bank Umum Syariah di Indonesia. JAE (Jurnal Akuntansi dan Ekonomi), 5(2), 100-111.

Otoritas Jasa Keuangan. (2016, January 27). POJK Nomor 4/POJK.03/2016. Diambil kembali dari https://www.ojk.go.id/id/kanal/perbankan/regulasi/peraturan-ojk/Pages/pojk-tentangpenilaian-tingkat-kesehatan-bank-umum.aspx

Otoritas Jasa Keuangan. (2017, Maret 17). Surat Edaran Otoritas Jasa Keuangan Nomor 14/SEOJK.03/2017. Diambil kembali dari https://www.ojk.go.id/id/kanal/perbankan/regulasi/surat-edaran-ojk/Pages/SuratEdaran-Otoritas-Jasa-Keuangan-Nomor-14-SEOJK.03-2017.aspx

Safaat, N. (2015). Pemograman Aplikasi Mobile Smartphone dan Tablet PC Berbasis Android. Bandung: Informatika Bandung.

Shalahuddin, \& Rosa. (2015). Rekayasa Perangkat Lunak Tersruktur dan Berorientasi Objek. Bandung: Informatika.

Taruna, R. D., \& Setiawan, S. (2019). Pengaruh Kinerja Keuangan Terhadap Pertumbuhan Laba Bank Umum di Indonesia. Jurnal Accounting Information System (AIMS), 2(1), 69-78.

Wijaya. (2007). Pengertian Data Flow Diagram (DFD). Jakarta: Elex Media.

Wizcasase. (2020, Agustus 1). Diambil kembali dari Wizcase: https://id.wizcase.com/blog/23statistik-mengagumkan-pada-internet-dan-media-sosial/ 